\title{
The anti-inflammatory effect of the Ribes nigrum species
}

\author{
Efectul antiinflamator al speciei Ribes nigrum \\ Daniel CORD ${ }^{1}$, Mariana POPESCU ${ }^{1}$, Iulia BURGHIU HOBEANU², \\ Roxana Colette SANDULOVICI ${ }^{1}$, Anca Daniela RAICIU ${ }^{1}$ \\ ${ }^{1}$ Catedra Farmacognozie, Fitochimie, Fitoterapie, Facultatea de Farmacie „Titu Maiorescu“, \\ Bucureşti, România \\ ${ }^{2}$ Rețeaua privată de sănătate „Regina Maria“, Bucureşti, România
}

\begin{abstract}
Introduction. Blackcurrant (Ribes nigrum L.) is a frequently grown cultivated in different parts of the world with a temperate climate. Fruits have a sour taste and they are rich rich source of vitamin $C$ and rutine, organic acids, pectins, essential oils, as well as micro- and macronutrients.

Material and method. Several studies have recently been carried out on several vegetable materials in order to find antioxidant and anti-inflammatory substances for the use of vegetable products in various food products or medicinal preparations as substitutes for synthetic substances.

Results and discussions. Ribes nigrum contains a large number of phenolic compounds. The blackcurrant shows a number of heal th benefits attributed to the anti-inflammatory and antioxidant potential.
\end{abstract}

Keywords: osteoarthritis, anti-inflammatory, phytotherapy, gemmotherapy, gemma, Ribes nigrum, Salix alba, Vitis vinifera, gemoderivatives

\section{REZUMAT}

Introducere. Coacăzul negru (Ribes nigrum L.) este un arbust frecvent cultivat în diferite părți ale lumii cu climă temperată. Fructele au gust acrişor fiind o sursă bogată de vitamina $C$ şi rutină, acizi organici, pec-tinele, uleiurile esențiale, precum şi micro- şi macronutrienți.

Material şi metodă. Recent, s-au efectuat mai multe studii asupra mai multor materiale vegetale, în scopul de a găsi substanțe antioxidante şi antiinflamatoare pentru utilizarea produselor vegetale în diferite produse alimentare sau preparate medicinale ca înlocuitori pentru substanțele sintetice.

Rezultate şi discuții. Ribes nigrum conține un număr foarte mare de compuşi fenolici. Coacăzul negru prezintă o serie de beneficii pentru sănătate atribuită potențialului antiinflamator şi antioxidant.

Cuvinte cheie: gonartroză, antiiinflamator, fitoterapie, gemoterapie, muguri, Ribes nigrum, Salix alba, Vitis vinifera, gemoderivate

\section{INTRODUCERE}

Coacăzul negru (Ribes nigrum L.) este un arbust frecvent cultivat în diferite părți ale lumii cu climă temperată. Fructele au gust acrișor fiind o sursa bogata de vitamina $C$ și alte substanțe benefice sănătății cum ar fi: rutină, acizi orga- nici, pectinele, uleiurile esențiale, precum și micro- și macronutrienți (14).

Genul Ribes a fost clasificat în familia Saxifragaceae inițial, dar mai târziu a fost plasată în cadrul familiei Grossulariaceae pe baza unor caracteristici morfologice cum ar fi prezența ova- 
relor inferioare, a gimnospermelor și a fructelor cărnoase (5).

\section{TABELUL 1}

\begin{tabular}{|l|l|}
\hline Regn Plantae & Ordin Saxifragales \\
\hline Diviziune Magnoliophyta & Familie Grossulariaceae \\
\hline Clasa Magnoliopsida & Gen Ribes \\
\hline & Specie R. nigrum \\
\hline
\end{tabular}

Fitoterapia este studiul extractelor naturale utilizate pentru îngrijirea sănătății (8). Anumite plante sau părți ale acestora, luate ca alimente, pot avea efecte terapeutice. Fiecare civilizație timpurie a folosit plante sau părți ale plante (muguri, frunze, muguri, flori, fructe, semințe, scoarță, rădăcini) ca sursă principală de tratare a bolilor, iar acest lucru este valabil chiar și în ziua de azi (3). În plus, există o tendință mai mare spre utilizarea regulată a terapiilor alternative în principalele țări europene. În Franța 49\% din populație iar în Germania 46\% folosește în mod regulat terapiile complementare (11). Astfel că numărul consumatorilor de medicamente naturale a crescut doar în anul 2012 cu până la 7,5\% în rândul populației (9).

Gemoterapia este una dintre cele mai recente tehnici terapeutice dezvoltate pe baza proprietăților medicale ale plantelor. Acesta utilizează proprietățile extractelor obținute prin macerarea în etanol și glicerol ale țesuturilor meristematice proaspete ale plantelor, în special muguri și lăstari, în scopuri medicinale. Datorită cantității mari de compuși bioactivi, multe dintre plante acționează sinergic, existând o preferință pentru atribuirea efectului farmacologic al „fitocomplexului“ întâlnită la orice compus activ, la fel ca în cazul medicinei standard (7).

\section{MATERIAL ŞI METODĂ}

Recent, s-au efectuat mai multe studii asupra mai multor materiale vegetale, în scopul de a găsi substanțe antioxidante (16) și antiinflamatoare pentru utilizarea produselor vegetale în diferite produse alimentare sau preparate medicinale ca înlocuitori pentru substanțele sintetice.

În fitocomplexul de R.nigrum (Fig. 1) (au fost considerate valori medii) s-au evidențiat acizi organici $(50,98 \%)$ și polifenoli $(29,39 \%)$, urmat de monoterpene $(14,04 \%)$ și vitamine $(5,98 \%)$ (6).

Într-o analiză recentă HPLC-DAD a extractului etanolic din frunze de coacăz negru, numai acidul clorogenic și izomerul său acidul neo-clo-

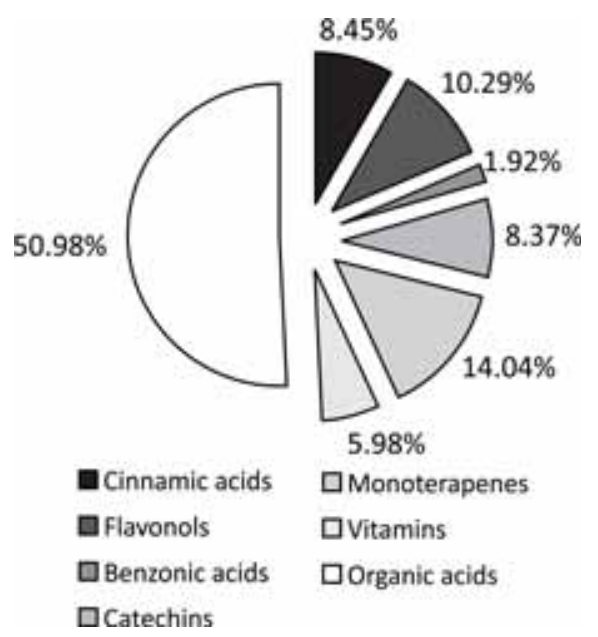

FIGURA 1

*(după Dario Donno și colab)

rogenic au fost cuantificate, iar concentrațiile lor au variat de la 0.081-0.121 mg/g greutate uscată respectiv 0.044-0.435 mg/g greutate uscată (19).

Într-un extract etanolic din frunze de coacăze din Estonia, concentrația acidului clorogenic este mult mai mare (14,93 $\mathrm{mg} / \mathrm{g}$ frunze uscate) determinată prin analiza HPLC-MS (20). În ceea ce privește flavonoli, kaempferol și quercetină (Fig. 2) acestea au fost prezente în frunzele Ribes nigrum.

Vagiri și colab. (19) au identificat quercetin3-O-rutinoside $(0.099-0.229 \mathrm{mg} / \mathrm{g}$ greutate uscată), quercetin-3-O-galactozid (0.057-0.081 $\mathrm{mg} / \mathrm{g}$ greutate uscată),quercetin-3-O-glucozid (0,038-0.085 mg/g greutate uscată), quercetin3-O-malonilglucosidă (2.424-3.890 mg/g greutate uscată). În plus, kaempferol-3-O-rutinosidă (0.019-0.036 mg/g greutate uscată), kaempferol-3-O-glucozid (0.017 la $0.031 \mathrm{mg} / \mathrm{g}$ greutate uscată), kaempferol-3-O-malonilglucozidă (0.135-0.409 mg/g greutate uscată), un al doilea izomer (0.488-2.441 mg/g greutate uscată), precum și miricetin-malonilglucosidă (0.042-0.055 $\mathrm{mg} / \mathrm{g}$ greutate uscată) și izomerul acesteia (0.019-0.023 mg/g greutate uscată) (19).

Analiza HPLC-MS a extractului din frunze de coacăze negre de origine estoniană a scos în evidență două glucozide majore, quercetin glucozida (quercetrin) și rutinosida (rutin), ale extractului etanolic, acestea fiind găsite în concentrații mari (19.47 și 3.99 mg/g frunze uscate, respectiv) (20).

Mai mult, izoramnetin-3-O-rutinoside, izoramnetin-3-O-glucozid, kaempferol-3-O-galactozidă și kaempferol-3-O-glucozil-6 au fost prezente în extractul etanolic de Ribes nigrum (15). 
Catechina (Fig. 2) și epicatechina (Fig. 2) au fost detectate în frunze, chiar dacă nu în mod constant; concentrația de catechine din extractul etanolic din frunze de coacăz negru a fost de $7,89 \mathrm{mg} / \mathrm{g}$.

Identificarea antocianilor s-a realizat pe baza timpului de retenție, pe baza analizei spectrale de masă UV-VIS, comparativ cu standardele și datele din literatura de specialitate (13). Absorbanța a fost înregistrată la 520 nm (Fig. 3).

Cromatogramele obținute au relevat prezența a numeroasă a antocianilor și a derivaților lor în produsele analizate. Identificarea peakului, timpii de retenție, identificarea și concentrațiile acestora sunt prezentate mai jos.
TABELUL 2

\begin{tabular}{|l|l|l|l|}
\hline $\begin{array}{l}\text { Peak } \\
\mathbf{n r}\end{array}$ & $\begin{array}{l}\text { Rt } \\
(\mathbf{m i n})\end{array}$ & Denumirea peak-ului & Concentrația \\
\hline 1 & 10,72 & Delphinidin-3-O-glucoside & $22.1 \pm 1.34$ \\
\hline 2 & 11,77 & Delphinidin-3-O-rutinoside & $57.97 \pm 2.29$ \\
\hline 3 & 14,80 & Cyanidin-3-O-glucoside & $9.8 \pm 1.82$ \\
\hline 4 & 16,01 & Cyanidin-3-O- rutinoside & $50.5 \pm 1.60$ \\
\hline
\end{tabular}

O diferență semnificativă între fructe și frunze o reprezintă concentrația de antociani mai mică în frunze; delfinidină-3-O-glucozida și -rutinosida, precum cianidina-3-O-glucozida (4). O altă diferență este absența acizilor hidroxibenzoici. Cu toate acestea, frunzele de coacăze conțin substanțe importante, cum ar fi glicerolipide<smiles>O=c1c(O)c(-c2ccc(O)c(O)c2)oc2cc(O)cc(O)c12</smiles>

FIGURA 2

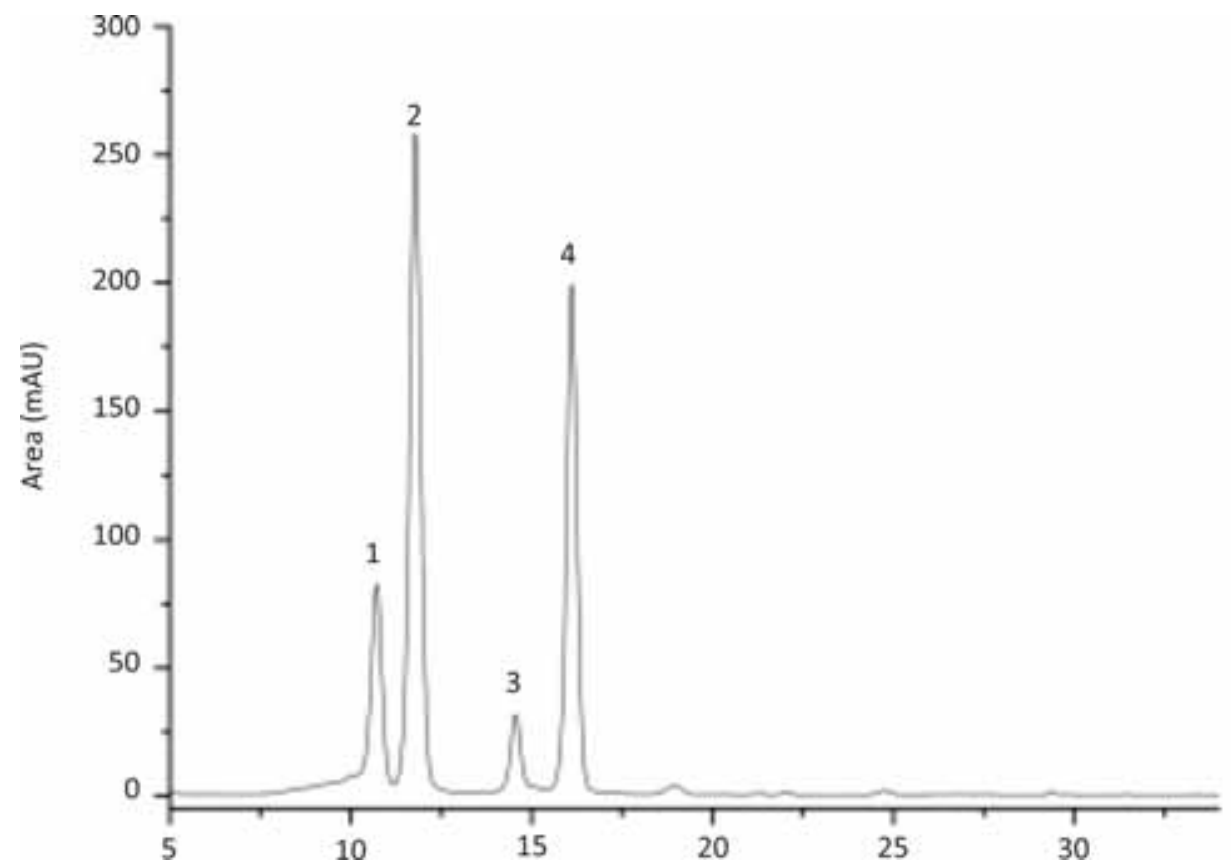

FIGURA 3. Cromatograma unor antociani prezenți în Ribes nigrum 


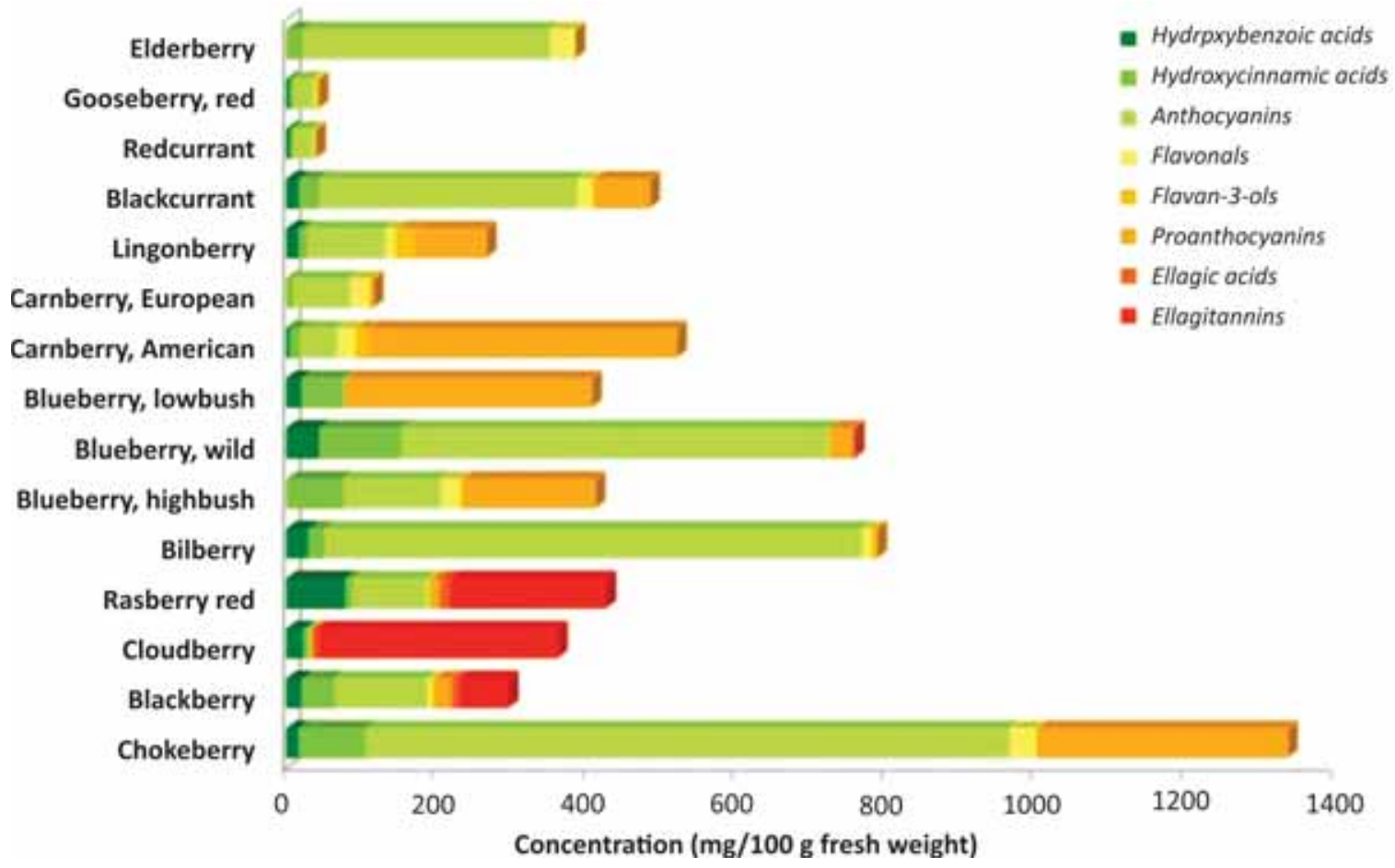

FIGURA 4. Compoziția fenolică a fructelor de pădure

*(După Anastasia-Varvara și colab.)

(acid alfa-linoleic, în principal) și acid ascorbic (1-2.70 mg/g de material uscat) (4). În final, uleiul esențial din frunzele de Ribes nigrum conține în principal substanțe monoterpenice ( $\alpha$-pinen, mircen, $p$-cimen, limonen, $\beta$-ocimene), sescviterpenele, cariofilene și humulene, precum și salicilat de metil (2).

În ceea ce privește flavonoidele prezente în coacăzul negru, acestea conțin cea mai mare concentrație de flavonoli, în special derivații quercetin și miricetină și aglicon (1). Coacăzele roșii conțin numai urme de flavonoli (1).

Culoarea strălucitoare a fructelor de coacăz negru se datorează antocianilor, care sunt distribuiți în principal în țesuturile epidermice ale fructelor în cantități substanțiale. În fructele de coacăz negru găsim ca antocianine cianidinul glicozilat.

\section{REZULTATE ŞI DISCUȚII}

Ribes nigrum conține un număr foarte mare de compuși fenolici. Coacăzul negru este numit uneori "super-fruct", deoarece el prezintă o serie de beneficii pentru sănătate (13) atribuite potențialului antiinflamator și antioxidant.

\section{Acțiunea antiinflamatoare}

Inflamația este strâns legată de diverse boli, cum ar fi ateroscleroza, boli cardiovasculare, ac- cident vascular cerebral, cancerul, diabetul zaharat, artrita, astm, migrene, dureri, periodontita, sindromul de colon iritabil, sindromul oboselii cronice, chiar și infecțiile microbiene $(21,25)$. În prezent, medicamentele utilizate pentru tratamentul bolilor inflamatorii cronice sunt în principal diferite medicamente nesteroidiene, care pot exercita efecte secundare. Prin urmare, dezvoltarea unor surse eficiente și naturale de produse anti-inflamatorii a căpătat o atenție sporită. Dovezile acumulate în ultimii ani au subliniat faptul că Ribes nigrum posedă activități antiinflamatoare, prin diverse mecanisme de acțiune $(15,25)$.

Studiile indică faptul că flavonoidele prezente în Ribes nigrum prezintă proprietăți antiinflamatoare. Fructele de coacăz negru modulează răspunsul inflamator al celulelor, cu scăderea NFjB, TNFa și IL-6 (13).

Frunzele au propietăți atât antioxidante cât și antiinflamatoare și prin inhibarea activității mieloperoxidazei și a producției de specii reactive de oxigen neutrofil activate, așa cum a fost demonstrat prin modele celulare biologic relevante, care dovedesc utilizări tradiționale (22). Aceste efecte sunt corelate cu ingredientele fenolice care sunt sintetizate inițial de plantă pentru a se proteja de agenți patogeni (10). Prin urmare, s-a propus ca frunzele de Ribes nigrum să fie folosite pentru extracții la scară largă da- 
torită proprietăților antiinflamatoare și antioxidante.

În plus, studiile pe edem al labei șobolanului indus de către caragenan a scos la iveală potențialele proprietăți analgezice ale frunzelor de coacăz, datorită inhibării proantocianinei infiltrate la nivel leucocitar.

Tratamentul gemoterapic pentru afecțiunile inflamatorii este constituit în principal din extractul glicerinohidroalcolic 1DH: mugurii.

Gonartroza este o afecțiune cronică degenerativă a articulației, având ca rezultat deteriorarea invalidantă a articulației. Se produce practic o uzură progresivă a cartilajului articular, care își pierde suplețea, apărând durerea și limitarea mobilității genunchiului.

În cazul unui pacient cu gonartroză, cartilajul articular se uzează progresiv, devine aspru și neregulat, și astfel alunecarea dintre extremitățile osoase este anevoioasă și dureroasă.

Simptomele sunt cu mult mai evidente și de o intensitate sporită dimineața sau după o perioadă de inactivitate: durerea și dificultatea de a mobiliza genunchiul, însoțite de tumefierea articulației, mers șchiopătat.

Extractele glicerohidroalcoolice din muguri de Ribes nigrum, muguri de Salix alba și muguri de Vitis Vinifera îmbină acțiunea aniinflamatoare și analgezică, fără a avea însă efectele adverse ale antiinflamatoarelor nesteroidiene.

Astfel, substanța activă a gemoderivatului de muguri de Salix Alba este binecunoscuta salicină, care nu irită tubul digestiv. Salicina prin hidroliză formează glucoză și saligenină (alcool salicilic). Saligenina se oxidează în ficat rezultând acidul salicilic care are proprietăți analgezice, antipiretice și antireumatice.

Extractul glicerinohidroalcoolic din muguri de Ribes nigrum datorită proprietăților sale antinflamatoare și acțiunii cortizon-like este utilizat în tratamentul poliartritei reumatoide. Mugurii de coacăz negru au concentrații mari de vitamina C (107 mg/g) și de aminoacizi esențiali.

Autorii prezintă rezultatele unui studiu de caz, observațional, alcătuit din două loturi: LOT A (lot de studiu) și LOT B (lot martor), fiecare format din 10 pacienți cu diagnosticul de gonartroză bilaterală.

Pe durata studiului, pacienților din lot A li s-a administrat timp de 3 luni:

- Dimineața - o monodoză de Gemoderivat din muguri de Ribes nigrum;

- Prânz - o monodoză de Gemoderivat din muguri de Salix alba;
- seara - o monodoză de Gemoderivat din muguri Vitis Vinifera.

Pacienții din ambele loturi au fost monitorizați clinic și paraclinic (probe inflamatorii: VSH, fibrinogen, proteina $C$ reactivă), la începutul studiului (momentul TO) și la final (momentul T1).

La pacienți a fost evaluat gradul de mobilitate articulară prin timpul de deplasare pe o suprafață plană prestabilită.

Evaluarea statistică a rezultatelor s-a efectuat prin testul "t" student și ANOVA.

Valorile serice ale probelor inflamatorii ale pacienților din lotul A au scăzut în urma tratamentului cu gemoderivatele din muguri Ribes nigrum, muguri de Salix alba și din muguri de Vitis Vinifera pentru VSH cu $13,48 \%$, pentru fibrinogen cu $14,26 \%$, iar pentru proteina $C$ reactivă cu 11, 52\%. Pacienții din lotul B au prezentat variații nesemnificative din punct de vedere statistic.

Comparativ cu lotul martor, pacienții din lotul A au avut o mai mare flexibilitate articulară, ameliorarea durerii articulare până la dispariție, lucruri demonstrate atât subiectiv cât și obiectiv prin măsurarea timpului de deplasare pe o suprafață plană prestabilită. Astfel, pacienții din lotul $A$ au avut o scădere a timpului de parcurgere a suprafeței plane în medie cu $36,74 \%$. Pacienții din lotul B nu au avut diferențe semnificative statistic ale timpului de parcurgere a suprafeței plane în momentul T1 față de momentul TO.

Schema de tratament general este:

- Adulți și copii peste 7 ani: 1 monodoză de 2,0 $\mathrm{ml}$ de 2-3 ori pe zi, cu 15 minute înainte de masă (dimineața și prânz), în asocieri 1 monodoză de $2 \mathrm{ml}$ odată pe zi dimineața.

- Copii între 2 și 7 ani: 1/2 din doza adultului, numai la recomandarea medicului.

\section{Activitatea antivirală}

Ribes nigrum prezintă proprietăți antivirale detectate la extractele brute ale acestuia împotriva tipurilor de virus gripal de tip A și B (VIA și VIB). La o concentrație de $3,2 \mu \mathrm{g} / \mathrm{ml}$, formarea plăcii atât IVA și IVB a fost inhibată de extract cu 50\% (IC50). În plus, atunci când se tratează celulele gazdă cu 10 și $100 \mu \mathrm{g} / \mathrm{ml}$ extract timp de 6 ore după infectare, creșterea IVA ar putea fi complet suprimată. Titrurile de virus în fluidele de cultură ale celulelor au fost complet suprimate după tratament cu $100 \mu \mathrm{g} / \mathrm{ml}$ de extract timp de 1 oră după infectare cu 8 până la 9 ore, indicând faptul că extractul inhibat a eliberat virusul din celulele infectate (18). 


\section{CONCLUZII}

În fitocomplexul de R.nigrum (au fost considerate valori medii) s-au evidențiat acizi organici $(50,98 \%)$ și polifenoli $(29,39 \%)$, urmat de monoterpene $(14,04 \%)$ și vitamine $(5,98 \%)$. Flavonoidele prezente în coacăzul negru conțin cea mai mare concentrație de flavonoli, în special derivații quercetin și miricetină și aglicon. Culoarea strălucitoare a fructelor de coacăz negru se datorează antocianilor, care sunt distribuiți în principal în țesuturile epidermice ale fructelor în cantități substanțiale. Ribes nigrum posedă activități antiinflamatorii, prin diverse mecanisme de acțiune.

Flavonoidele prezente în Ribes nigrum prezintă, proprietăți antiinflamatoare. Fructele de coacăz negru modulează răspunsul inflamator al celulelor, cu scăderea NFjB, TNFa și IL-6.

Mecanismele protective ale meristemelor vegetale sunt intens cercetate și demonstrate. Astfel, prin scăderea valorile serice ale probelor inflamatorii la pacienții din lotul A, comparative cu cei din lotul B martor, se demonstrează efectul antiinflamator al extractelor glicerohidroalcoolice utilizate.

Toate efectele benefice ale gemoterapiei pot fi puse pe seama modulării activității telomerazei umane, ipoteză care este în plină cercetare și dezbatere.

Conflict of interest: none declared Financial support: none declared

\section{BIBLIOGRAFIE}

1. Anastasia-Varvara Ferlemi, Fotini N. Lamari, Dorothy Klimis-Zacas, Berry Leaves: An Alternative Source of Bioactive Natural Products of Nutritional and Medicinal Value, 5(2), 17; doi:10.3390/antiox5020017, 2016, Antioxidants, ISSN 2076-3921

2. Andersson J., Bosvik R., Von Sydow E., The composition of the essential oil of black currant leaves (Ribes nigrum L.), J. Sci. Food Agric., 1963;14:834-840. doi: 10.1002/ jsfa.2740141110, 2016, ISSN: 0022-5142

3. Balunas M.J., Kinghorn A.D., Drug discovery from medicinal plants, Life Sci., 78(5):431-41, 2005, ISSN: 0024-3205

4. Committee on Herbal Medicinal Products (HMPC), Assessment Report on Ribes nigrum L., Folium, European Medicines Agency, pp.3-17, 2010, EMA/ HMPC/142989/2009

5. Cronquist A., An integrated system of classification of flowering plants. Columbia university press, pp.1260, 1981, ISBN 0231038801,9780231038805

6. Dario Donno, Maria Gabriella Mellano, Alessandro Kim Cerutti, Gabriele Loris Beccaro, Biomolecules and Natural Medicine Preparations: Analysis of New Sources of Bioactive Compounds from Ribes and Rubus spp. Buds, Pharmaceuticals, 9(1): 7,2016, ISSN 1424-8247

7. Donno D., Beccaro G.L., Cerutti A.K., Mellano M.G., Bounous G., Bud extracts as new phytochemical source for herbal preparations: Quality control and standardization by analytical fingerprint, In: Rao A.V., Rao L.G., editors. Phytochemicals Isolation, Characterisation and Role in Human Health. Volume 1. InTech; Rijeka, pp. 187-218, 2015,

ISBN 978-953-51-2170-1
8. Donno D., Boggia R., Zunin P., Cerutti A.K., Guido M., Mellano M.G., Prgomet Z., Beccaro G.L., Phytochemical fingerprint and chemometrics for natural food preparation pattern recognition: An innovative technique in food supplement quality control, J. Food Sci. Technol., doi: 10.1007/s13197-015-2115-6, 2015, ISSN: 0975-8402

9. Fürst R, Zündorf I. Evidence-Based Phytotherapy in Europe: Where Do We Stand?, Planta Med., 81(12-13):962-7, 2015, ISSN : 0032-0943

10. Grayer R.J., Kokubun T., Plant--fungal interactions: the search for phytoalexins and other antifungal compounds from higher plants. Phytochemistry. 56(3):253-63, 2001, ISSN 1572-980X

11. Konik E.A., Jungling R.C., Bauer B.A., Herbs and dietary supplements in the European Union: a review of the regulations with special focus on Germany and Poland, J. Diet Suppl., 8(1):43-57, 2011, ISSN: 1939-022X

12. Knox Y.M., Suzutani T., Yosida I., Azuma M., Anti-influenza virus activity of crude extract of Ribes nigrum L., Phytother. Res., 17:120-122. doi: 10.1002/ptr.1053. 2003, ISSN: 1099-1573

13. Lyall, K. A., Hurst, S. M., Cooney, J., Jensen, D., Lo, K., Hurst, R.D. et al., Shortterm blackcurrant extract consumption modulates exercise-induce oxidative stress and lipopolysaccharide-stimulated inflammatory responses. American Journal of Physiology - Regulatory, Integrative and Comparative Physiology, 297, R70-R81, 2009, ISSN 0363-6119

14. Mattila P.H., Hellstrom J., McDougall G.et al., Polyphenol and vitamin $\mathrm{C}$ contents in European commercial blackcurrant juice products, Food Chemistry, vol. 127, no. 3, pp. 1216-1223, 2011, ISSN: 0308-8146
15. Mihele D., Raiciu A. D., Manea St., Pop A., Research regarding the antiinflammatory action of some gemoderivatives, European Journal of Drug Metabolism and Pharmacokinetics, 13th Pan-Hellenic Pharmaceutical congress, 12-14 May, 32, Atena, pg.55, 2007, ISSN: 0378-7966

16. Ong E.S., Extraction methods and chemical standardization of botanicals and herbal preparations. J. Chromatogr B Analyt Technol Biomed Life Sci., 812(1-2):23-33, 2004, ISSN: 1570-0232

17. Raiciu A.D., Giurginca M., Mihele D., Manea Şt., Pop A., Determining the antioxidant activity of certain gemoderivates, 7th Joint Meeting of AFERP, ASP, GA, PSE \& SIF, Natural Products with Pharmaceutical, Nutraceutical, Cosmetic and Agrochemical interest, Planta Medica,74, Neumarkt, pg. 995-1228, 2008, ISSN : 0032-0943

18. Raiciu A.D., Setnic S., Mihele D., Manea Şt., Determinarea compoziției chimice a unor gemoderivate prin metoda HPLC, Revista medico-chirurgicala a Societatii de Medici si Naturalisti din lasi, Supliment nr. 4, 113, (2), laşi, pg. 364-370, 2009, ISSN:0048-7848

19. Raudsepp P., Kaldmae H., Kikas A., Libek A.V., Püssa T., Nutritional quality of berries and bioactive compounds in the leaves of black currant (Ribes nigrum L.) cultivars evaluated in Estonia, Journal of Berry Reserch, 1:53-59, 2010, ISSN 1878-5123

20. Rubinskiene M., Jasutiene I., Venskutonis P.R., Viskelis P., HPLC determination of the composition and stability of blackcurrant anthocyanins, J. Chromatogr Sci., 43(9):478-82, 2005, ISSN 0021-9665

21. Seeram N.P., Berry fruits: compositional elements, biochemical activities, and the 
impact of their intake on human health, performance, and disease, J. Agric Food Chem., 56(3):627-9, 2008, ISSN: 1520-5118

22. Tabart J., Franck T., Kevers C.,

Pincemail J., Serteyn D., Defraigne J.O., Dommes J., Antioxidant and anti-

inflammatory activities of Ribes nigrum

extracts. J. Food Chem., 131:1116-1122.

doi: 10.1016/j.foodchem.2011.09.076,2012, ISSN: 1520-5118
23. Vagiri M., Conner S., Stewart D., Andersson S.C., Verrall S., Johansson E., Rumpunen K., Phenolic compounds in blackcurrant (Ribes nigrum L.) leaves relative to leaf position and harvest date, Food Chem., 1720:135-42, 2015, ISSN: 0308-8146

24. Vagiri M., Ekholm A., Andersson S.C., Johansson E., Rumpunen K.J. An optimized method for analysis of phenolic compounds in buds, leaves and fruits of black currant (Ribes nigrum L.), J. Agric Food Chem., 60(42):10501-10, 2012, ISSN: 1520-5118

25. Ya Li, Jiao-Jiao Zhang, Dong-Ping Xu, Tong Zhou, Yue Zhou, Sha Li, Hu Bin Li, Maurizio Battino, Bioactivities and Health Benefits of Wild Fruits, Int J Mol Sci., 2016, ISSN 1422-0067 